\title{
Bydraende faktore tot leerderdissiplineprobleme: 'n Multiveranderlike analise
}

\begin{tabular}{|c|c|}
\hline $\begin{array}{l}\text { Authors: } \\
\text { Cecile Eloff }{ }^{1} \\
\text { Izak J. Oosthu } \\
\text { Charl C. Wolh } \\
\text { Johannes L. v }\end{array}$ & $\begin{array}{l}\text { izen } \\
\text { uter }^{1} \\
\text { an der Walt }{ }^{2}\end{array}$ \\
\hline $\begin{array}{l}\text { Affiliations: } \\
{ }^{1} \text { School of Ed } \\
\text { North-West } \\
\text { Potchefstroor } \\
\text { South Africa }\end{array}$ & $\begin{array}{l}\text { cation, } \\
\text { niversity, } \\
\text { Campus, }\end{array}$ \\
\hline $\begin{array}{l}{ }^{2} \text { Faculty of Ed } \\
\text { Sciences, Nor } \\
\text { University, M } \\
\text { South Africa }\end{array}$ & $\begin{array}{l}\text { ucation } \\
\text { h-West } \\
\text { fikeng Campus, }\end{array}$ \\
\hline $\begin{array}{l}\text { Corresponde } \\
\text { Charl Wolhut }\end{array}$ & $\begin{array}{l}\text { ice to: } \\
\text { er }\end{array}$ \\
\hline $\begin{array}{l}\text { Email: } \\
\text { charl.wolhute }\end{array}$ & r@nwu.ac.za \\
\hline $\begin{array}{l}\text { Postal addre } \\
\text { Private Bag X } \\
\text { Potchefstroor } \\
\text { South Africa }\end{array}$ & $\begin{array}{l}\text { s: } \\
\text { 2501, } \\
2520,\end{array}$ \\
\hline $\begin{array}{l}\text { Dates: } \\
\text { Received: } 30 \\
\text { Accepted: } 26 \\
\text { Published: } 25 \\
\text { Republished: }\end{array}$ & $\begin{array}{l}\text { Nov. } 2012 \\
\text { July } 2013 \\
\text { Oct. } 2013 \\
\text { 21 Feb. } 2014\end{array}$ \\
\hline $\begin{array}{l}\text { How to cite } t \\
\text { Eloff, C., Oost } \\
\text { I.J., Wolhuter } \\
\text { Van der Walt, } \\
\text { 'Bydraende fa } \\
\text { leerderdissipl } \\
\text { 'n Multiveran } \\
\text { Koers - Bullet } \\
\text { Scholarship } 7 \\
7 \text { pages. http } \\
\text { org/10.4102/ }\end{array}$ & $\begin{array}{l}\text { is article: } \\
\text { luizen, } \\
\text { C.C. \& } \\
\text { J.L., 2013, } \\
\text { ktore tot } \\
\text { neprobleme: } \\
\text { lerlike analise', } \\
\text { n for Christian } \\
\text { (3), Art. \#449, } \\
\text { //dx.doi. } \\
\text { koers.v78i3.449 }\end{array}$ \\
\hline $\begin{array}{l}\text { Note: } \\
\text { Article repub } \\
\text { corrected aut } \\
\text { Johannes L. v }\end{array}$ & $\begin{array}{l}\text { shed with the } \\
\text { hor affiliation of } \\
\text { in der Walt. }\end{array}$ \\
\hline $\begin{array}{l}\text { Copyright: } \\
\text { (C) 2013. The } \\
\text { Licensee: AO } \\
\text { OpenJournals } \\
\text { is licensed un } \\
\text { Creative Com } \\
\text { Attribution Li }\end{array}$ & $\begin{array}{l}\text { uthors. } \\
\text { IS } \\
\text { This work } \\
\text { ler the } \\
\text { nons } \\
\text { ense. }\end{array}$ \\
\hline 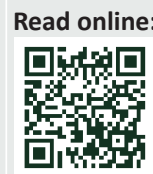 & $\begin{array}{l}\text { Scan this QR } \\
\text { code with your } \\
\text { smart phone or } \\
\text { mobile device } \\
\text { to read online. }\end{array}$ \\
\hline
\end{tabular}

Tot op hede was navorsers geneig om elkeen van die oorsaaklike of bydraende faktore tot leerderdissiplineprobleme in skole afsonderlik van mekaar te benader. Hierdie artikel het oor navorsing rakende die teoreties-regverdigbare samevloeiing van hierdie faktore rakende dissiplineprobleme in klaskamers gerapporteer. Graad 9-leerders en hulle opvoeders (onderwysers) het vraelyste voltooi waarin hulle op 'n semantiese differensiaalskaal moes aantoon tot watter mate hulle meen elkeen van die 36 moontlike oorsake 'n rol speel in die voorkoms van dissiplineprobleme in hulle skool. Roetinefaktoranalise het aan die lig gebring dat veral sewe faktore ' $n$ bydrae lewer tot wangedrag in hulle besondere skool, naamlik sosiale probleme in die gemeenskap, ouers se invloed op die leerders se gedrag, die gesag van die opvoeder, demokratiese deelname van die rolspelers aan die skoolbestuur, die skoolstrukture as 'n invloed op die voorkoms van leerderwangedrag, asook fisiese geremdhede en psigologiese gestremdhede.

Contributory factors to learner discipline problems: A multivariate approach. Hitherto, researchers in the field of the various causal or contributory factors of learner discipline problems in schools tended to approach each of those factors in isolation. This article reported on research regarding the theoretically justifiable notion of the confluence of the various factors that culminate in learner discipline problems at school. Grade 9 learners as well as their educators completed questionnaires in which they had to indicate on a semantic differential scale the extent to which they thought each of the 36 possible causes played a role in the incidence of learner discipline problems in their school. Routine factor analysis revealed that seven factors contributed to learner misbehaviour in their particular school, namely social problems in society, the influence of parents on the behaviour of their children, the authority of the educator, democratic participation in school governance, the nature of school structures, and also physical and psychological disabilities.

\section{Inleiding en probleemstelling}

Suid-Afrikaanse skole ondervind reeds 'n geruime tyd probleme met dissipline, met die gevolg dat doeltreffende onderrig en leer in baie gevalle nie kan plaasvind nie (cf. Wolhuter, Oosthuizen \& Van Staden 2010; Rossouw \& Smit 2013). Voordat 'n probleem soos hierdie behoorlik verstaan en reggestel kan word, moet die grondliggende oorsake daarvan en die bydraende faktore daartoe eers begryp word. Tot dusver het navorsing oor leerderdissiplineprobleme op Suid-Afrikaanse bodem hoofsaaklik op die persepsies van dissipline gefokus asook die voorkoms en hantering van sodanige probleme (cf. Mabeba \& Prinsloo 2000; Mangena 2002; Maboe 2005; Mabitla 2006; Masitsa 2007; Eloff 2009). Soos aangetoon sal word, handel hierdie studies oor die oorsaaklike of bydraende faktore tot leerderdissiplineprobleme en net soos in internasionale navorsing daaroor, word elkeen van hierdie faktore in isolasie beskou. Hoe hierdie onderskeie faktore in die praktyk in interaksie met mekaar tot leerderdissiplineprobleme aanleiding gee of gegee het, het ongelukkig nie die nodige aandag geniet nie (cf. Steyn et al. 2003).

Die doel van hierdie artikel is om 'n uiteensetting te gee van die navorsing waarmee gepoog is om hierdie leemte in die wetenskaplike literatuur te vul. Om in hierdie doel te slaag, is die artikel soos volg gestruktureer: Eerstens word 'n konseptueel-teoretiese raamwerk aangebied waarin 'n verheldering van die begrip dissipline gedoen word en die teorie rakende die oorsake en bydraende faktore tot leerderdissiplineprobleme krities beoordeel word. Daarna word die empiriese ondersoek uiteengesit, waarna die bevindings van die ondersoek gerapporteer en bespreek word.

\section{Konseptueel-teoretiese raamwerk Begripsverheldering}

Die begrip dissipline word deur Labuschagne en Eksteen (1993:141) verklaar as gehoorsaam aan owerhede, selfbeheersing, ordelike gesag en bestraffing, terwyl Joubert en Prinsloo (2001:119) 
aandui dat die woord van die Latynse woord disco afkomstig is, wat beteken om te leer, asook van disciplina wat na die oordrag van kennis aan 'n leerder verwys. Volgens Fernhout (1997:88) hou die woord ook verband met die woord dissipel, wat volgeling beteken. Op grond van hierdie semantiese aanduidings kan die begrip leerderdissipline soos volg omskryf word.

Leerderdissipline verwys enersyds na die leiding, toerusting en instaatstelling wat van ' $n$ meer volwasse persoon uitgaan na 'n leerder as die minder volwasse persoon, terwyl laasgenoemde fisies, psigies en intellektueel ontwikkel met die oog op selfverwesenliking en volwassewording. Andersyds verwys leerderdissipline na die regstellende ingryping in laasgenoemde se gedrag wanneer die leerder se gedrag nie aan die gestelde opvoedings-, maatskaplike en omgewingsnorme en -verwagtings voldoen nie. In die normale verloop van sake verwys die term leerderdissiplineprobleme na laasgenoemde saak, naamlik 'n situasie waar die leerder se gedrag en optrede nie aan die eise, norme en verwagtings voldoen wat kenmerkend en aanvaarbaar is in die betrokke omgewing - soos 'n skool - nie. In sodanige gevalle word dan ook meermale verwys na 'leerderwangedrag'. Leerderdissiplineprobleme of leerderwangedrag vereis ingryping ter regstelling. Die ingrepe en pogings tot regstelling wat van die kant van die meer volwasse persoon kom, soos 'n ouer of onderwyser as opvoeder, moet uiteraard pedagogies van aard wees. Laasgenoemde beteken dat dit opbouend (konstruktief) en vormend gerig moet wees op, soos dit in die definisie genoem is, die leiding, toerusting en instaatstelling van die leerder as opvoedeling. Kortom, dit moet lei tot dissipelvorming by die leerder, dit wil sê, 'n bereidheid om te volg, 'n volgeling te wees op 'n meer gewenste lewenspad.

\section{Oorsaaklike of bydraende faktore tot leerderdissiplineprobleme}

Volgens Cangelosi (2004:355) is die oorsake van leerderdissipline die gevolg van verskeie meewerkende faktore wat meebring dat leerders nie betrokke is by hulle eie leerproses nie. In die literatuur is vyf stelle oorsaaklike of bydraende faktore tot leerderdissiplineprobleme geïdentifiseer (Wolhuter, Oosthuizen \& Van Staden 2006:5), naamlik samelewings-, ouer-, skool-, opvoeder- en leerderverwante faktore.

Samelewingsverwante faktore, dit wil sê politieke, ekonomiese en maatskaplike toestande, speel 'n groot rol in die manifestering van leerderwangedrag. ' $n$ Historiese kultuur van geweld in 'n samelewing kan byvoorbeeld tot gevolg hê dat leerders begin glo dat hulle hulle probleme deur middel van aggressie en geweld in die skool kan oplos (De Villiers 1997:96). Van der Walt, Potgieter en Wolhuter (2009) toon ook hoedat 'n gebrek aan sosiale kapitaal in die Suid-Afrikaanse samelewing 'n teelaarde vir leerderdissiplineprobleme kan wees. Mabitla (2006:19) beweer daarbenewens dat leerders wat uit gebroke en disfunksionele gesinne soos enkelouergesinne kom waar sterfte of egskeiding voorgekom het, baie kwesbaar is en gevolglik ' $n$ risiko is ten opsigte van aggressie, omdat hulle verwerping, onverskilligheid en vyandigheid ervaar.

Ouers speel op twee opvoedingsterreine 'n rol, naamlik eerstens in die begeleiding (opvoeding) van die kind en tweedens deur hulle skool(on)betrokkenheid (Mentz, Wolhuter \& Steyn 2003:400-401). Internasionaal is daar 'n negatiewe verband gevind tussen ouers se betrokkenheid by die skool en die dissiplineprobleme van hulle kinders by die skool (Wolhuter \& Steyn 2003:531). Oueronbetrokkenheid in Suid-Afrikaanse skole word gekenmerk deur 'n swak opkoms by oueraande, beperkte betrokkenheid by insamelingsprojekte, onwilligheid om skoolfonds te betaal en 'n gebrek aan belangstelling by die leerders se skoolwerk (Mestry \& Grobler 2007:177). Verdere faktore wat ouerbetrokkenheid kortwiek, is die swak kommunikasie van die skool met die ouers, onder meer weens onopgeleide opvoeders wat nie weet hoe om na die ouers uit te reik nie (Mestry \& Grobler 2007).

Op Suid-Afrikaanse bodem het Rossouw (2003:426) vasgestel dat ouers indirek op een of albei van die volgende maniere tot leerderwangedrag bydra: eerstens deur die disfunksionele ouerhuise wat hulle aan die kinders bied (waar faktore soos armoede, ongeletterde ouers, ouers wat nie belangstel in die kinders en hulle opvoeding nie, HIV en VIGS hoogty vier) en tweedens deur gebrekkige ouerlike sorg.

Skoolverwante faktore hou verband met die bestuur van die skool as organisasie. Van der Westhuizen, Oosthuizen en Wolhuter (2008) het in 'n gevallestudie van 'n Suid-Afrikaanse skool getoon hoedat 'n skoolkoshuisorganisasiekultuur met goeie bestuur doelbewus geskep kan word om goeie leerderdissipline te bevorder.

Leerderverwante faktore het te doen met alle aspekte van die leerder se fisiese, affektiewe en sosiale ontwikkeling. Wolhuter et al. (2010) het in 'n empiriese ondersoek in SuidAfrikaanse skole vasgestel dat die voorkoms van verskillende leerderdissiplineprobleme varieer in ooreenstemming met die betrokke skoolfase (grondslag-, intermediêre, senior- en verdere onderwysfases).

Wat opvoederverwante faktore betref, is daar in die internasionale literatuur eenstemmigheid dat die opvoeder se bekwaamheid ' $n$ invloed het op die stand en gehalte van leerderdissipline in skoolklasse (Wolhuter \& Steyn 2003:527). Opvoeders kan as bekwaam beskou word sodra hulle wydbelese is in die hantering van dissipline en moeilike klassituasies vanuit 'n kennisbasis en begrip kan benader (Miller \& Pedro 2006:295). 'n Vereiste vir die bewerkstelliging van goeie leerderdissipline sluit in dat die opvoeders hulle gesagsposisie op 'n redelike en regverdigbare wyse volgens regtelike prosedures bekragtig (Mestry \& Grobler 2007:181). De Klerk-Luttig en Heystek (2007:4) dui aan dat 'n swak opvoeder-leerderverhouding, opvoeders wat nie rolmodelle is nie en opvoeders wat hulself aan wangedrag skuldig maak, die leerderdissipline by 'n skool negatief kan beïnvloed. 
Soos verduidelik, is daar al vele ondersoeke, internasionaal en hier in Suid-Afrika gedoen en gepubliseer oor die verskillende bydraende faktore tot leerderdissiplineprobleme. Oor die uitwerking van die sameloop van hierdie faktore en hoe hulle neig om in dissiplineprobleme in die klaskamer uit te mond, is nog nie ondersoek ingestel nie. Die ondersoek waaroor hierna verslag gedoen word, was 'n poging om hierdie leemte te vul.

\section{Waarom word die samevloeiing van faktore ondersoek?}

Die vraag kom aan die orde waarom dit dan nodig is om die gesamentlike uitwerking te ondersoek van die faktore wat moontlik'n rol in die ontstaan van leerderdissiplineprobleme in klaskamers kan speel. Waarom is dit nie teoreties en prakties voldoende om te volstaan met 'n verstaan van die uitwerking en die rol van elke individuele faktor nie? Hoekom moet bepaal word watter faktore intern konsistent met mekaar saamhang in hulle uitwerking op leerdergedrag?

Die sleutel tot hierdie vraag kan 'n mens onder meer vind in die capabilities approach soos dit deur Nussbaum, Sen en andere ontwikkel is. Nussbaum (2000) skryf dat human capabilities [menslike vermoëns] verwys na:

what people are actually able to do and to be - in a way informed by an intuitive idea of life that is worthy of the dignity of the human being. [Wat mense in staat is om te doen en in staat is om te wees - op 'n manier geïnformeer deur ' $n$ intuïtiewe idee van ' $n$ lewe wat menswaardigheid waardig is.] (bl. 5, [outeurs se eie vertaling])

Uit haar stelling is dit al duidelik dat sy van oordeel is dat die vermoëns (capabilities) van die mens nie een vir een, individueel, nagegaan behoort te word nie, dog wel in samehang omdat dit belangrik is vir die waardigheid van die mens. Dit is ook uit haar verdere uiteensetting duidelik waarom sy die mens so wil benader: sy beskou die mens as 'n organiese eenheid binne ' $n$ bepaalde holistiese omgewing (Nussbaum 2000:12). Dieselfde gedagte is deur Sen (2010:233) uitgespreek. Robeyns (2005) som Sen se siening op, deur te stel dat alles wat die mens is en doen, al sy en haar funksioneringsaspekte, bydra om die betrokke individu se hele lewe waardevol te maak. Robeyns (2005) waarsku dat die individu in hierdie proses nie atomisties bekyk moet word nie, dog altyd ook in sosiale en maatskaplike konteks.

Die gedagte van 'n (organiese) eenheid of heelheid hou verband met integriteit. Volgens Van Rensburg (2012:10) en Noshulwana (2011:16) dui die woord integriteit oorspronklik op heelheid. Vanuit die Christelike standpunt fundeer Van Rensburg hierdie betekenis op Efesiërs 4:28, Spreuke 19:1, Psalm 82:4 en Spreuke 10:4. Integriteit, voer hy aan, dui op die saamloop van gedagtes en woorde, die heelheid van gedagtes en woorde (1 Kor 4:19; Matt 23:19; Rom 12:3). Dieselfde gedagte kom ook by Kubow (2011:157) voor wanneer sy aanvoer dat die 'edele mens van goeie karakter' iemand is 'who demonstrates a consistent pattern of integrity in both private and public affairs' [wat'n konsekwente patroon van integriteit in sy of haar privaat- sowel as openbare lewe vertoon]. Die mens is integer, heel of 'n geheel, redeneer Parekh (2000:147), omdat die mens 'n wese is met waardigheid, 'n waardigheid wat nie bekom word nie, maar wat inherent deel van die mens se wese of syn is. Die mens is 'n spirituele eenheid, stem Schneller (2011:171) saam.

Hoewel die mens 'n saambundeling van 'n hele aantal modaliteite of funksionele aspekte is, insluitende die sosiale, die etiese en die ekonomiese, om enkeles te noem, is die mens 'n geheel (integer), 'n eenheidswese. Hoewel die mens 'n groot aantal eienskappe vertoon, in verskillende modaliteite funksioneer en verskillende rolle in verskeie samelewingsverbande kan vervul, bly die mens 'n integrale eenheid, wat innig tot ' $n$ eenheid vervleg is. Hierdie gedagte word goed in die Bybel saamgevat in 1 Korintiërs 12:12 en in Psalm 139:13. Geen enkele aspek van menswees kan dus in isolasie bekyk word nie. Dit geld ook die faktore en omstandighede wat die mens noop tot swak dissipline of wangedrag. Hoewel elkeen van hierdie faktore vir wetenskaplike ondersoek geïsoleer of geabstraheer kan word, bly hulle onderling innig verweef, omdat hulle almal op die een of ander wyse antropologiese figure is; hulle hou almal met die wesenlike van die antropos, die mens, verband.

\section{Empiriese ondersoek Navorsingsontwerp}

'n Opname-ontwerp is gebruik.

\section{Doel van die opname}

Deur middel van die opname is ' $n$ poging aangewend om die menings van die deelnemers in te win oor watter van die faktore wat aan hulle voorgehou is, oorsaaklike of bydraende faktore tot die leerderdissiplineprobleme in hulle skole was.

\section{Populasie en steekproefneming}

Die studiepopulasie was die graad 9-leerders en hulle opvoeders in die omgewing van ' $n$ middelgroot stad in die Noordwesprovinsie van Suid-Afrika. In elkeen van die 14 skole wat ingestem het om aan die navorsing deel te neem, is twee graad-9-klasse ewekansig gekies (leerderdeelnemers $n=735$ ), en twee of meer graad-9-opvoeders (onderwysers) betrek wat bereid was om die vraelys in te vul (opvoederdeelnemers $n=29$ ). Wat die opvoeders betref, is gebruik gemaak van 'n beskikbaarheidsteekproef.

\section{Etiese oorwegings}

Toestemming is aangevra en van die Noordwesonderwysdepartement ontvang asook van die skoolhoofde van die skole waarin die ondersoek gedoen is. Alle betrokkenes, leerders sowel as opvoeders (onderwysers), is oor die doel van die ondersoek ingelig, hulle is verseker dat hulle deelname vrywillig sou wees en dat hulle te enigertyd aan die ondersoek kon onttrek indien iets hulle verontrus. Nie een het egter onttrek nie. Die deelnemers is ook daarvan verseker dat hulle response vertroulik en anoniem hanteer sou word. 
'n Onderneming is ook aan die betrokke skoolhoofde gegee dat die bevindings van die ondersoek aan hulle gerapporteer sou word. Die ondersoek is verder deur die Etiese Komitee van die Universiteit, onder wie se toesig dit uitgevoer is, goedgekeur.

\section{Navorsingsinstrument}

'n Selfopgestelde vraelys met 38 items is gebruik wat ál vyf bovermelde kategorieë van oorsaaklike of bydraende faktore tot leerderdissiplineprobleme dek. (Die vraelys verskyn in Bylaag 1.) Op elkeen van die items moes die deelnemers op die volgende vierpuntskaal hulle mening gee ten opsigte van die mate waarin hulle saamstem dat die betrokke item 'n oorsaaklike of bydraende faktor tot leerderdissiplineprobleme op skool is:

1. Verskil geheel en al

2. Verskil gedeeltelik

3. Stem in 'n mate saam

4. Stem volkome saam.

\section{Geloofwaardigheid}

Die gesigsgeldigheid van die instrument is verseker deur elkeen van die verskillende items daarin te fundeer in die konseptueel-teoretiese raamwerk wat hierbo beskryf is.

Die interne konsistensie, konsekwentheid of konstrukgeldigheid van die verskillende faktore is bepaal deur die Cronbach-alpha-koëffisiënt daarvan te bereken. Die koëffisiënt van faktor 1 was 0.76 en was dus betroubaar ( $>0.70)$; dié van faktor 2 was 0.59 en gevolglik nie betroubaar nie $(<0.70)$; faktor 3 se 0.77 was weer betroubaar $(>0.70)$, maar die 0.45 van faktor 4 was nie betroubaar nie $(<0.70)$; en faktor 5 se 0.51 was ook nie betroubaar nie $(<0.70)$, terwyl die 0.80 van faktor 7 wel betroubaar was $(>0.70)$.

\section{Data-insameling}

Die vraelys is oor ' $n$ tydperk van ses weke deur een van die navorsers by die verskillende skole afgeneem. Weens hierdie persoonlike en direkte insamelingsmetode is al die vraelyste volledig ingevul terugontvang.

\section{Dataverwerking}

Die response is deur middel van die statistiese tegniek van faktoranalise verwerk, dit is 'n veelvuldige regressieanalise waar meer as twee veranderlikes ter sprake is. As sodanig is dit 'n uitstekende tegniek om die verhouding of ko-variasie tussen baie veranderlikes te ondersoek (Wolhuter 1997:166). Elke veranderlike (in hierdie studie is dit die getal items in die vraelys) se verhouding tot al die ander veranderlikes is op hierdie manier gepeil. Die doel van hierdie prosedure was om 'n groot aantal veranderlikes tot 'n klein klompie faktore te reduseer. Die korrelasiekoëffisiënt tussen elke veranderlike en elke faktor is voorts bereken (Wolhuter 1997:167).

\section{Bevindings}

Sewe faktore is geïdentifiseer, naamlik een wat samelewingsfaktore insluit, een wat ouerverwante faktore insluit, een wat opvoederverwante faktore insluit, twee wat op die skoolbestuur betrekking het en twee wat op leerderkenmerke betrekking het. Hierdie sewe faktore was dus die volgende:

1. Sosiale probleme in die gemeenskap wat tot leerderwangedrag bydra. Agt items is by hierdie faktor onderskei.

2. Ouers se invloed op die leerders se gedrag. Vier items val onder hierdie faktor.

3. Die gesag van die opvoeder as 'n bydraende faktor tot leerderwangedrag. Nege items ressorteer onder hierdie faktor.

4. Demokratiese deelname van die rolspelers aan die skoolbestuur. Ten opsigte van hierdie faktor geld vier items.

5. Die skoolstrukture as 'n invloed op die verskynsel van leerderwangedrag. Twee items is by hierdie faktor geïdentifiseer.

6. Leerderhindernisse wat tot leerderwangedrag bydra. Sewe items is by hierdie faktor onderskei.

7. Fisiese geremdhede en gestremdhede wat tot leerderwangedrag bydra. Vier items is by hierdie faktor onderskei.

Die items wat by elke faktor bepaal is, asook elke item se faktorlading word in Tabel 1, op die volgende bladsy, aangetoon.

\section{Bespreking}

Uit die voorafgaande uiteensetting van die bevindings blyk dat die samevloeiing van eienskappe van die moderne Suid-Afrikaanse samelewing in faktor 1, naamlik geweld en armoede, ook oorspoel na die gesin as die primêre sosiale groep van die samelewing. Volgens die leerder- en opvoederrespondente lê hierdie situasie ten grondslag van die leerderdissiplineprobleme in die betrokke skole. Fisiese, sosiale en opvoedkundige afstand, dit wil sê die gebrek aan ' $n$ 'ons'-ruimte tussen ouers en hulle kinders, is ook ' $n$ oorsaak van leerderdissiplineprobleme in skole (faktor 2). Wat die opvoederfaktore betref (faktor 3), is die sterkste bydraende faktore, volgens die opvoederresponse, die probleme wat die opvoeders ervaar met die implementering van die nuwe kurrikulum, asook die kwessie van opvoeders wat onseker is oor hoe hulle die leerders effektief kan dissiplineer. Albei hierdie verskynsels spruit voort uit die nuwe onderwysomgewing waarin opvoeders hulle deesdae bevind, naamlik die eise van die implementering van 'n nuwe kurrikulum en die eise van 'n onderrigomgewing waar dissiplineringsmetodes van die verlede (soos fisiese straf) nie meer toegepas (mag) word nie. Volgens die leerders is onsekerheid by hulle opvoeders 'n sterk faktor, asook die feit dat min van hulle onderwysers vir hulle as rolmodelle (kan) dien.

Die demokratisering van die skoolbestuur (faktor 4 en faktor 5) deur leerders en veral opvoeders word voorts beskou as 'n sterk aanleidende oorsaak of bydraende faktor tot leerderdissiplineprobleme. Die gemiddelde waardes in die laaste twee kolomme is hoër as vir enige van die ander faktore. Dit kom egter nie ooreen met die leer van positiewe 
TABEL 1: Items wat op die verskillende faktore betrekking het.

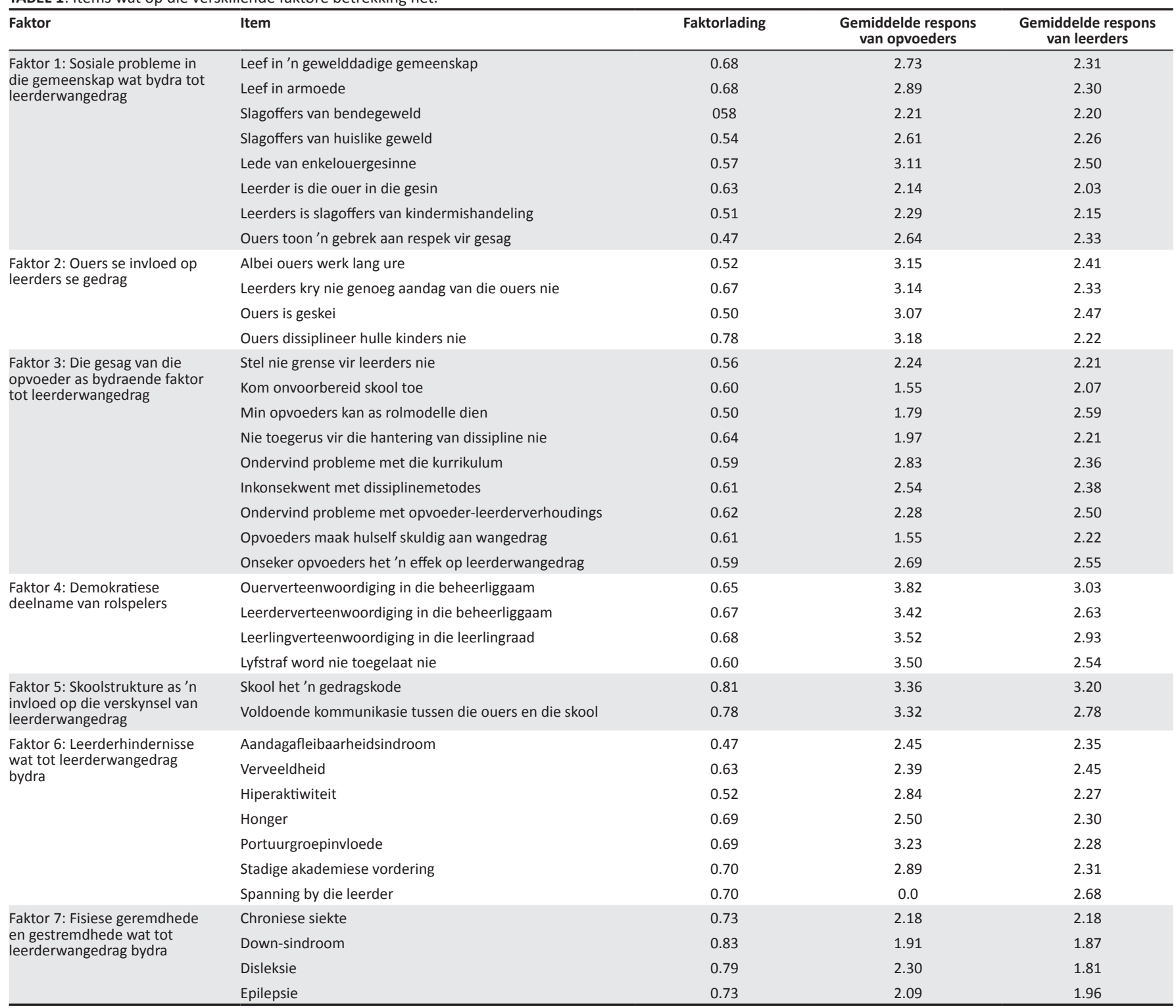

dissipline (cf. Van der Walt, Potgieter \& Wolhuter 2010) nie, veral nie met die Lovegrovemodel (cf. Lovegrove, Lewis \& Burman 1989) nie. Hierdie model word in die internasionale literatuur as die demokratisering van bestuur voorgehou wat bevorderlik is vir goeie leerderdissipline. Volgens sowel die opvoeders as die leerders is fisiese gestremdhede en geremdhede nie 'n deurslaggewende faktore by die ontstaan van leerderdissiplineprobleme nie. (Die gemiddeldes is telkens onder die 2.5-middellyn tussen 'stem saam' en 'stem nie saam nie'.) Leerderhindernisse (psigiese en sosiale probleme) kan wel sterk bydra tot die teenwoordigheid van leerderdissiplineprobleme. Die rangordes van die opvoeders en die leerders verskil egter. Die opvoeders slaan die invloed van die portuurgroep, hiperaktiwiteit en stadige akademiese vordering hoog aan, terwyl die leerders spanning weer hoog gradeer. Volgens die opvoeders is spanning onder leerders egter geen faktor nie.

Laastens, om die sirkel te voltooi, sluit faktor 1 aan by faktor 2. Dit blyk dat daar nie slegs tussen ouers en kinders 'n kommunikasiegaping en ontoereikende bewuswees van mekaar se wêrelde bestaan nie, maar ook tussen die opvoeders en die leerders.

Hierdie bevindings bevestig die uitgangspunt dat die mens 'n organiese, integere eenheid of geheel is. Die feit dat so 'n groot verskeidenheid bydraende of veroorsakende faktore 'n rol by die ontstaan van leerderwangedrag kan speel met gevolglike leerderdissiplineprobleme hou verder verband met die feit dat die mens, in hierdie geval die leerder, oor 'n groot aantal vermoëns (capabilities) beskik. Mense is, soos Nussbaum dit veronderstel, inderdaad in staat om baie dinge te wees en te doen. Daarin lê hulle waardigheid - ten spyte van die wangedrag wat hulle vertoon. Vanuit 'n Christelike perspektief sou 'n mens kon sê dat hulle waardigheid nie net spruit uit wat hulle kan wees, dink of doen nie, maar veral omdat hulle die handewerk van God is en na sy beeld geskep is. Hierdie ondersoek beklemtoon die feit dat hoewel dit belangrik is om die afsonderlike vermoëns (capabilities) van die mens apart na te gaan, dit ook wel in samehang bestudeer 
moet word, omdat dit belangrik is vir die waardigheid van die mens as 'n organiese eenheid binne 'n bepaalde holistiese omgewing. Al die mens se funksioneringsaspekte dra inderdaad by om die betrokke individu se hele lewe waardevol te maak.

\section{Slotopmerking}

Die ondersoek wat in hierdie artikel gerapporteer is, bring aan die lig dat hoewel dit belangrik is om die verskillende faktore wat tot leerdisssiplineprobleme aanleiding gee van tyd tot tyd individueel te ondersoek, die tyd aangebreek het om na te gaan watter uitwerking hulle gesamentlik op leerderdissipline(probleme) het. Hierdie ondersoek toon dat 36 verskillende bydraende faktore in die praktyk tot net sewe (7) hooffaktore saamvloei, wat weer in mekaar invloei en tot leerdissiplineprobleme in skole aanleiding gee. Soos uit die konseptueel-teoretiese raamwerk geblyk het, kan hierdie samevloeiingstendens bes moontlik toegeskryf word aan die feit dat die mens 'n eenheidswese is. Sowel die opvoeder as die leerder ervaar op integere en holistiese wyse die heelheid van al die faktore wat op hulle inwerk en wat tot probleme en struikelblokke in die pedagogiese situasie kan aanleiding gee.

\section{Erkenning \\ Mededingende belange}

Die outeurs verklaar dat hulle geen finansiële of persoonlike verbintenis het met enige party wat hulle nadelig of voordelig kon beïnvloed in die skryf van hierdie artikel nie.

\section{Outeursbydrae}

C.E. (Noord-Wes Universiteit), I.J.O. (Noord-Wes Universiteit), C.C.W. (Noord-Wes Universiteit) en J.L.v.d.W. (Noord-Wes Universiteit) het gelyke bydraes gelewer tot die skryf van hierdie artikel.

\section{Literatuurverwysings}

Cangelosi, S., 2004, Classroom management strategies: Gaining and maintaining student cooperation, 5 th edn., Wiley, New Jersey.

De Klerk-Luttig, J. \& Heystek, J., 2007, 'Discipline in schools: Are our student teachers ready for the challenge?', proceedings of Perspectives on learner conduct: First International Conference on Learner Discipline, North-West University, Potchefstroom Campus, April 02-04, 2007, pp. 1-13.

De Villiers, A.P., 1997, 'Inefficiency and the demographic realities of the South African school system [Ondoeltreffendheid en die demografiese realiteite van die SuidAfrikaanse skoolstelsel]', South African Journal of Education 17, 67-80.

Eloff, CH., 2009, 'Die hantering van leerderwangedrag in sekondêre skole', ongepubliseerde M.Ed-verhandeling, Fakulteit Opvoedkunde, Noordwes-Universiteit.

Fernhout, H., 1997, 'Christian schooling: Telling a world view story', in I. Lambert \& S. Mitchell (eds.), The crumbling walls of certainty, pp. 75-90, Centre for the Study of Australian Christianity, Sydney.

Joubert, H.J. \& Prinsloo, I.J., 2001, Education law: A practical guide for educators, Van Schaik, Pretoria.

Kubow, P.K., 2011, 'The creative spirit and comparative education', in P.L. Schneller \& C.C. Wolhuter (eds.), Navigating the C's: An introduction to comparative education, pp. 155-168, Keurkopié, Potchefstroom.
Labuschagne, F.J. \& L.C. Eksteen, 1993, Verklarende Afrikaanse woordeboek, 8e uitg., Van Schaik, Pretoria.

Lovegrove, M., Lewis, R. \& Burman, E., 1989, 'Classroom discipline', in P. Langford (ed.), Educational psychology, pp. 255-281, Longman, Melbourne.

Mabeba, M.Z. \& Prinsloo, E., 2000, 'Perceptions of discipline and ensuing discipline problems in secondary education [Persepsies van dissipline en daaropvolgende probleme met dissipline in die sekondêre onderwys]', South African Journal of Education 20(1), 34-41.

Mabitla, M.A., 2006, 'Causes and manifestations of aggression among secondary school learners', MEd dissertation, Faculty of Education, University of South Africa.

Maboe, T.P., 2005, 'Educational law basis for parental involvement in the school system', MEd dissertation, Faculty of Educational Sciences, North-West University.

Mangena, L.T., 2002, 'The protection of human rights: An analysis of approaches to school discipline', MPhil thesis, Dept. of Philosophy, University of Stellenbosch.

Masitsa, M.G., 2007, 'Discipline and punishment in township schools in South Africa: Unresolved problems', proceedings of Perspectives on learner conduct: First International Conference on Learner Discipline, North-West University, Potchefstroom Campus, April 02-04, 2007, pp. 155-165.

Mentz, P.J., Wolhuter, C.C. \& Steyn, S.C., 2003, "n Perspektief op die voorkoms van dissiplineprobleme in Afrikaanse skole', Koers - Bulletin for Christian Scholarship 68(4), 391-412.

Mestry, R. \& Grobler, B., 2007, 'Collaboration and communication as effective strategies for parent involvement in public schools [Samewerking en kommunikasie as effektiewe strategieë vir die ouer-betrokkenheid in openbare skole]', Educationa Research and Review 2(7), 176-185.

Miller, R. \& Pedro, J., 2006, 'Creating respectful classroom environment [Die skepping van 'n respekvolle klaskamer-omgewing]', Early Child Education Journal 33(5), 293-299.

Noshulwana, V., 2011, 'Integrity and what it really means in an age of entitlement', The Herald, 17 February, p. 16

Nussbaum, M.C., 2000, Women and human development: The capabilities approach Cambridge University Press, Cambridge.

Parekh, B., 2000, 'Non-ethnocentric universalism', in T. Dunne \& N.J. Wheeler (eds.), Human rights in global politics, pp. 128-159, Cambridge University Press, Cambridge.

Robeyns, I., 2005, 'The capability approach: A theoretical survey [Die vermoëbenadering: 'n Teoretiese opname]', Journal of Human Development and Capabilities 6(1), 93-117.

Rossouw, J.P., 2003, 'Learner discipline in South African public schools: A qualitative study [Leerderdissipline in Suid-Afrikaanse openbare skole: ' $n$ Kwalitatiewe studie]', Koers - Bulletin for Christian Scholarship 68(4), 413-435.

Rossouw, J.P. \& Smit, M., 2013, 'Student discipline in South Africa', in C.J. Russo, I.J. Oosthuizen \& C.C. Wolhuter (eds.), Best practices for student misconduct on six continents, n.p., Littlefield \& Roman, New York.

Schneller, P.L., 2011, 'The creation spirit', in P.L. Schneller \& C.C. Wolhuter (eds.), Navigating the C's: An introduction to Comparative Education, pp. 169-192, Keurkopié, Potchefstroom.

Sen, A., 2010, The idea of justice, Penguin Books, London.

Steyn, S.C., Wolhuter, C.C., Oosthuizen, I.J. \& Van der Walt, J.L., 2003, "n Internasionale perspektief op leerderdissipline in skole', Suid-Afrikaanse Tydskrif vir Opvoedkunde 23(3), 225-232.

Van der Walt, J.L, Potgieter, F.J. \& Wolhuter, C.C., 2009, 'Addressing the discipline problem in South African schools by increasing the supply of social capital in problem in South African schools by increasing the supply of social capital in society: A position paper [Die aanspreek van die dissipline-probleem in Suid-
Afrikaanse skole deur die verhoging van die verskaffing van sosiale kapitaal in die Afrikaanse skole deur die verhoging van die verskaffing van sosiale kapitaal
samelewing: 'n Posisie artikel]', Journal of Educational Studies 8(1), 47-59.

Van der Walt, J.L., Potgieter, F.J. \& Wolhuter, C.C., 2010, 'Positiewe dissipline in die hande van die opvoeder', Tydskrif vir Christelike Wetenskap 46(1), 145-168.

Van der Westhuizen, P.C., Oosthuizen, I.J. \& Wolhuter, C.C., 2008, 'The relationship between an effective organizational culture and student discipline in a boarding school [Die verhouding tussen ' $n$ doeltreffende organisatoriese kultuur en student-dissipline in 'n kosskool]', Education and Urban Society 40(2), 205-225.

Van Rensburg, K.A.J., 2012, 'Om 'n mens te wees van integriteit', Die Kerkblad 115(3256), 10-11.

Wolhuter, C.C., 1997, 'Classification of national education systems: A multivariate approach 'Klassifikasie van nasionale onderwys stelsels: 'n Meerveranderlike benadering]', Comparative Education Review 47(2), 161-177.

Wolhuter, C.C., Oosthuizen, I.J. \& Van Staden, J.G., 2006, 'Die dissiplinesituasie aan die kaleidoskoop van Suid-Afrikaanse skole: Belewenis van opvoeders', referaat gelewer by die Opvoedkunde Vereniging van Suid-Afrika (OVSA)-kongres, Universiteit van die Vrystaat, Bloemfontein, 18-20 Januarie.

Wolhuter, C.C., Oosthuizen, I.J. \& Van Staden, J.G., 2010, 'Skoolfase/leerderouderdom as faktor in leerderdissipline in Suid-Afrikaanse skole', Tydskrif vir Christelike Wetenskap 46(1), 169-186.

Wolhuter, C.C. \& Steyn, S.C., 2003, 'Learner discipline at school: A comparative educational perspective' [Leerderdissipline in skole: 'n Vergelykend-opvoedkundige perspektief]', Koers - Bulletin for Christian Scholarship 68(4), 521-538. 


\section{Bylaag 1 \\ Die vrae in die vraelys}

In watter mate beskou $u$ elk van die volgende as 'n oorsaaklike/bydraende faktor tot leerderdissiplineprobleme in skole. Antwoord elke vraag deur een van die volgende moontlikhede te kies:

1. Verskil geheel en al

2. Verskil gedeeltelik

3. Stem in 'n mate saam

4. Stem geheel en al saam

1. Leerder woon in 'n geweldadige gemeenskap

2. Leerder leef in armoede

3. Albei ouers van die leerder werk lang ure

4. Leerder is 'n slagoffer van bende-aktiwiteite

5. Leerder beleef huislike geweld

6. Leerder is lid van 'n enkelouergesin

7. Die leerder is die ouer in die huisgesin'

8. Leerder ontvang nie genoeg aandag van ouers nie

9. Leerder se ouers is geskei

10. Leerder is die slagoffer van kindermishandeling

11. Leerder word nie deur ouer gedissiplineer nie

12. Ouers toon 'n gebrek aan respek vir gesag

13. Skool het 'n gedragskode

14. Daar is voldoende kommunikasie tussen ouers en skool

15. Daar is ouerverteenwoordiging in die beheerliggaam

16. Daar is leerderverteenwoordiging in die beheerliggaam
17. Lyfstraf word nie in ons skool toegelaat nie

18. Opvoeders stel nie vir leerders grense nie

19. Opvoeders kom onvoorbereid skool toe

20. Daar is min opvoeders wat as rolmodelle kan dien

21. Opvoeders is nie toegerus om dissipline te handhaaf nie

22. Opvoeders ondervind probleme met die kurrikulum

23. Opvoeders is inkonsekwent met hul dissiplinemetodes

24. Opvoeders ondervind probleme met die opvoederleerderverhoudings

25. Opvoeders maak hulle skuldig aan wangedrag

26. Onseker opvoeders het ' $n$ invloed op leerders se gedrag

27. Opvoeders stel nie vir leerders grense nie

Leerderkenmerke

28. Aandagafleibaarheidsindroom

29. Verveeldheid

30. Chroniese siekte

31. Down-sindroom

32. Disleksie

33. Epilepsie

34. Hiperaktiwiteit

35. Honger

36. Portuurgroepinvloede

37. Stadige akademiese vordering

38. Spanning by die leerder 